Trykt på Institut for statskundskab

Eftertryk uden kildeangivelse ikke tilladt

\title{
Abonnement 1974
}

7. argang 1974 er planlagt til at omfatte 4 numre. Abonnementspris kr. 25. Beløbet indbetales på giro 5045193 , og indbetaling kan ikke ske på anden måde.

\section{Tidligere numre af POLITICA}

Alle tidligere numre er udsolgt, undtagen:

5. årgang, nr. 1 - Eliteforskning

6. årgang, nr, 2 - Arbejdsmarkedsforhold

6. årgang, nr. 3 - Fremtidsforskning

7. årgang, nr. 1 - Statsvidenskab III

Enkeltnumre tilsendes ved indbetaling af kr. 6 på giro 5045193 , eller kan købes $i$ ekspeditionen, Institut for statskundskab.

\section{Beklagelse}

POLITICA beklager forsinkelsen af årgang 1974. Forsinkelsen er kun en forsinkelse - POLITICA er ikke gåst ind - postvæsenet har ikke svigtet. Redaktionen påtager sig alt ansvar for langsommeligheden. Endvidere kalder vi af praktiske årsager 8. årgang for 1975/76.

\section{Adresseforandring}

Adresseforandring bedes $i$ abonnenternes egen interesse meddelt post vasenet og ikke redaktionen.

\section{Manglende levering}

Klager over manglende levering af POLITICA skal rettes til postvæsenet og ikke til redaktionen.

Al henvendelse $i$ ovrigt bedes rettet skriftligt til poLITICA, Institut for Statskundskab, Universitetsparken, 8000 Arhus C. 